\title{
Diel variation in abundance and size of the seabob shrimp Xiphopenaeus kroyeri (Crustacea, Penaeoidea) in the Ubatuba region, Southeastern Brazil
}

\author{
SABRINA M. SIMÕES ${ }^{1,2}$, ROGERIO C. COSTA ${ }^{1,2}$, ADILSON FRANSOZO ${ }^{2}$ \\ and ANTONIO L. CASTILHO ${ }^{2,3}$ \\ ${ }^{1}$ LABCAM (Laboratório de Biologia de Camarões Marinhos e de Água Doce) \\ Departamento de Ciências Biológicas, Faculdade de Ciências, UNESP, Campus Bauru \\ Av. Luis Edmundo Carrijo Coube, 14-01, Vargem Limpa, 17033-360 Bauru, SP, Brasil \\ ${ }^{2}$ NEBECC (Núcleo de Estudos em Biologia, Ecologia e Cultivo de Crustáceos), Departamento de Zoologia \\ Instituto de Biociências, UNESP, Campus Botucatu, Distrito de Rubião Jr, s/n, 18618-970 Botucatu, SP, Brasil \\ ${ }^{3}$ Departamento de Biologia, Faculdade Estadual de Filosofia, Ciências e Letras de União da Vitória \\ Praça Coronel Amazonas, s/n, Centro, 84600-000 União da Vitória, PR, Brasil
}

Manuscript received on January 23, 2009; accepted for publication on November 19, 2009

\begin{abstract}
The objective of the present study was to analyze diel variation in the abundance and size of the seabob shrimp Xiphopenaeus kroyeri in the Ubatuba region, state of São Paulo, during the year 2000. In each season of the year, collections were made in the day and at night on 9 transects at depths ranging from 2 to $40 \mathrm{~m}$. The estimated shrimp amount was of 28,878 individuals. Although the catch rate was higher during the day (15,853 shrimp), this did not differ significantly from the catch at night $(13,025)$. The catch rate was higher in daytime on most transects, but was higher at night at locations where fine and very fine sand predominated. The majority of juveniles were caught during the day. The mean size (CL) was $14.43 \pm 4.02 \mathrm{~mm}$ for day and $14.82 \pm 4.28 \mathrm{~mm}$ for night samples, and the difference was significant (Student's $t$-test, $\mathrm{df}=2,429, \mathrm{t}=2.27, \mathrm{p}=0.02$ ). The largest individuals were caught during the night. None of the three models that have been proposed in the literature to account for differences in the diurnal catch pattern of penaeid species can be applied to X. kroyeri. Our results provide evidence that sediment type not only influenced the catch rate in the analyzed periods, but also determined which models might fit the behavior of this species.
\end{abstract}

Key words: abundance, distribution, Penaeidae, Xiphopenaeus kroyeri.

\section{INTRODUCTION}

The tropical marine shrimp fishery, mainly for penaeid shrimps, is a very old activity. In recent decades, the mechanization of fishing boats and the growth of shrimp fleets have intensified exploitation, which has caused declines and even collapse of these fisheries. In Brazil, with the significant decline of the shrimp Farfantepenaeus spp. since the 1980s (Paiva 1997), the population of $X$. kroyeri, commonly called as "sete-barbas", became the most important target and is already impacted be-

Correspondence to: Rogerio Caetano da Costa

E-mail: rccosta@fc.unesp.br cause of continuous indiscriminate harvesting, especially in the state of São Paulo (Costa et al. 2007).

Sediment type and depth have been emphasized as major variables affecting the distribution of the penaeid shrimps (Dall et al. 1990). Several studies have demonstrated the substrate influence on some shrimp biological processes, since shrimps live on the substrate or buried in it (Fuss Jr and Ogren 1966). The majority of species remains buried during the day and emerge at dusk, i.e., are most active in the period when they are least vulnerable to potential predators (Minello et al. 1987, Laprise and Blader 1992, Sogard and Able 1994, Dall et al. 1990, 
Negreiros-Fransozo et al. 1999). Moctezuma and Blake (1981) noted that juveniles remain unburied for a longer period than adults do, because they need more food as a result of their high growth rate. In addition, Penn (1984) noted that the type of substrat can affect burying behavior: in locations with silt and clay sediments, the turbidity of the water may be higher, and here the catch does not differ among the periods. In sandy locations, turbidity is lower and the shrimps are more abundant at night.

Xiphopenaeus kroyeri (Heller, 1862) is widely distributed in the western Atlantic (Virginia, USA, to Rio Grande do Sul, Brazil) and the eastern Pacific (Mexico to Peru) (Pérez-Farfante and Kensley 1997). However, recently, Gusmão et al. (2006) demonstrated through molecular data that $X$. kroyeri is distributed only in the Atlantic, while Xiphopenaeus riveti occurs in the Pacific. $X$. kroyeri is the second most important fishery resource in abundance in the Southeastern Brazil, and is the most heavily exploited benthic shrimp species on the coast of the state of São Paulo (D'Incao et al. 2002, Castro et al. 2005).

Most studies on $X$. kroyeri have been focused on their abundance and ecological distribution (Fransozo et al. 2002, Costa et al. 2007, Castilho et al. 2008), population structure, and reproductive biology (Nakagaki and Negreiros-Fransozo 1998, Fransozo et al. 2000, Castro et al. 2005). Studies of the variation in catch and size of the seabob shrimp during the day and night periods are practically nonexistent. The only study of this nature was carried out by Negreiros-Fransozo et al. (1999), in the same region as the present study, for the species of Penaeoidea, although it had been carried out in only two seasons of the year (summer and winter) and at mean depths of $3.5 \pm 0.5 \mathrm{~m}$. These authors found that the number of individuals of these species did not differ among the analyzed periods, although larger shrimps were more often found at dusk. At this location, silt and clay predominate (Costa et al. 2007). Although this previous study had been carried through in depths until $3.5 \mathrm{~m}$, one knows that in Ubatuba, which is in the north coast of the state of São Paulo, X. kroyeri was distributed preferentially down to a depth of $25 \mathrm{~m}$ (Costa et al. 2007). In the area of the present study, the sediment texture changes with depth, becoming sandier below $15 \mathrm{~m}$ (Costa et al. 2007) and, according to the pro- posal of Penn (1984), these factors can modify the catch pattern of a penaeid shrimp.

Thus, the objective of the present study was to analyze the diel variation in abundance and size of individuals of $X$. kroyeri that were caught down to a depth of $40 \mathrm{~m}$ in the Ubatuba region, on the northern coast of the state of São Paulo. We also investigated whether a change in sediment type might alter the catch rate between the day and night periods. The present study also provided information on the periods and regions that juveniles are more vulnerable to the fishing, therefore serving as framework for the determination and implantation of management plans that propitiate a sustainable fishing.

\section{MATERIALS AND METHODS}

Located along the northern coastline of the state of São Paulo, the Ubatuba region is an important area for crustacean research (Mantelatto and Fransozo 2000). The region is unique when compared to other areas along the Brazilian southern coast. This coastal area is enclosed be within a system of inlets, bays, canals, bayous, and rivers bordered by mangroves that together form estuaries rich in nutrients that are favorable for the establishment and development of the marine fauna. In addition, Ubatuba Bay is fairly pristine and used as a standard for comparison with other marine habitats that are strongly influenced by humans (Mantelatto and Fransozo 1999).

The collections were carried out in all four seasons of the year (summer, autumn, winter and spring) in day and night periods, in the Ubatuba region (Fig. 1), during the year 2000. The samples were taken along 9 bottom transects, at depths of 2, 5, 10, 15, 20, 25, 30, 35 and $40 \mathrm{~m}$. We used a commercial fishing boat equipped with two Mexican-type "double rig" nets. The mesh size of the nets was $20 \mathrm{~mm}$ knot-to-knot in the body, and $15 \mathrm{~mm}$ in the cod end. Trawls were conducted along each transect for 30 minutes, over a distance of approximately 2 kilometers. Specifics nets for the capture of the shrimpwhite were used to prevent the capture of the animals buried in the substratum, i.e., with lighter materials and a high number of floats. The boat speed was also changed from 1.5 to 2 knots.

We obtained the total wet weight (in grams) of the $X$. kroyeri caught in each trawl. We, then, took a ran- 


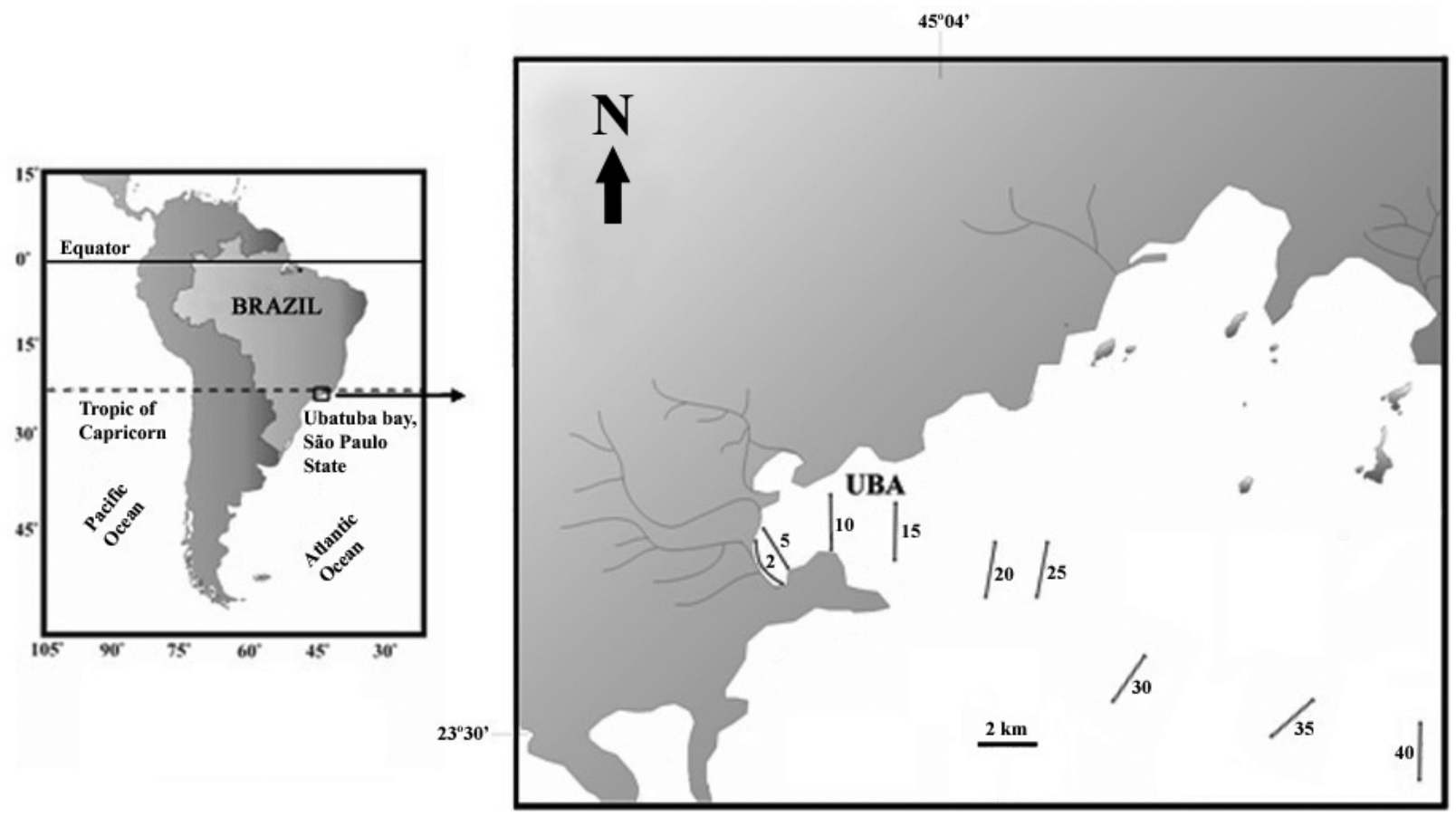

Fig. 1-Map of the Ubatuba (UBA) region.

dom 250-g subsample, and the number of individuals was counted on each transect of each season. Based on the data from the subsample and from the total biomass, it was possible to estimate the number of individuals for each transect, season, and period.

All the individuals in the subsample were measured for carapace length (CL $\mathrm{mm})$ in millimeters and were sexed. Carapace length, means the distance from the orbital angle to the posterior margin of the carapace. The reproductive condition of the females was determined by the macroscopic observation of the gonads, adapted from Bauer and Lin (1994) and Costa and Fransozo (2004), with four stages of development: IM = immature, RU $=$ rudimentary (adults with undeveloped gonads), ED $=$ developing, and $\mathrm{DE}=$ developed. The reproductive status of males was assessed by examining the shape of the petasma, which is fused in adult individuals (Castro et al. 2005).

The sediment was measured on each transect of each season. Details of the methodology are found in Bertini et al. (2001). The abundance of shrimp was compared among the seasons of the year and the transects, by means of analysis of variance (one-way ANOVA, $\mathrm{p}<0.05$ ), complemented by Tukey's multiple-compar- isons test, at the 5\% probability level. For each transect and season, the chi-square test $\left(\mathrm{X}^{2}\right)$ was used to compare the abundance of juveniles and adults between the sampled periods (day and night). The carapace size of individuals in each season and on each transect was compared between the day and night periods, by means of Student's $t$-test. Data were log-transformed prior to the analysis, to improve their normality (Zar 1999).

\section{RESULTS}

The highest mean values of sediment diameter (phi- $\Phi$ ) were found in the transects of 5 to $15-\mathrm{m}$ depth in all seasons (Table I).

The estimated shrimp amount was of 28,878 individuals: $22,993(80 \%)$ in winter, 3,042 (11\%) in summer, $2,562(8 \%)$ in autumn, and only $281(1 \%)$ in spring. The largest number of specimens $(24,678)$ was obtained on the 2 and 10-m transects; a total of 4,200 individuals were found on the 15 to $25-\mathrm{m}$ transects. No shrimp were collected on the 30,35 or 40-m transects. The number of individuals differed between spring and winter (one-way ANOVA, $\mathrm{p}=0.01$, $\mathrm{MS}=4.16$ and $\mathrm{F}=3.53$ ). The results for the transect comparisons are given in Table II. 
TABLE I

The mean diameter of the sediment (phi) at each transect during the seasons in the year 2000.

\begin{tabular}{c|c|c|c|c|c}
\hline \multicolumn{6}{c}{ phi $(\Phi)$} \\
\hline Transects & Summer & Autumn & Winter & Spring & Mean \pm SD \\
\hline $2 \mathrm{~m}$ & 5.93 & 3.48 & 5.98 & 5.93 & $5.33 \pm 1.06$ \\
\hline $5 \mathrm{~m}$ & 5.93 & 5.93 & 5.93 & 5.93 & $5.93 \pm 0.00$ \\
\hline $10 \mathrm{~m}$ & 6.18 & 6.18 & 6.18 & 6.18 & $6.18 \pm 0.00$ \\
\hline $15 \mathrm{~m}$ & 5.73 & 5.73 & 5.73 & 5.73 & $5.73 \pm 0.00$ \\
\hline $20 \mathrm{~m}$ & 4.28 & 4.28 & 4.28 & 4.28 & $4.28 \pm 0.00$ \\
\hline $25 \mathrm{~m}$ & 2.72 & 2.94 & 4.31 & 2.91 & $3.22 \pm 0.63$ \\
\hline $30 \mathrm{~m}$ & 3.08 & 3.08 & 2.74 & 2.94 & $2.96 \pm 0.13$ \\
\hline $35 \mathrm{~m}$ & 2.98 & 0.07 & 3.22 & 2.59 & $2.21 \pm 1.25$ \\
\hline $40 \mathrm{~m}$ & 4.19 & 4.02 & 4.18 & 2.27 & $3.66 \pm 0.80$ \\
\hline
\end{tabular}

$\mathrm{SD}=$ standard deviation

TABLE II

Numbers of individuals of Xiphopenaeus kroyeri collected in different periods (day and night) on the transects from 2 to $25 \mathrm{~m}$ depth and in the four seasons of the year. The results of Tukey's test are indicated by letters: the same letter indicates that the results did not differ significantly.

\begin{tabular}{c|c|c|c|c|c|c|c}
\hline Transect & Tukey & Period & Summer & Autumn & Winter & Spring & Total \\
\hline $2 \mathrm{~m}$ & $\mathrm{~A}$ & $\mathrm{D}$ & 948 & 1,017 & 4,933 & 5 & $\mathbf{6 , 9 0 3}$ \\
& & $\mathrm{N}$ & 1,072 & 235 & 4,310 & 15 & $\mathbf{5 , 6 3 2}$ \\
\hline \multirow{2}{*}{$5 \mathrm{~m}$} & $\mathrm{~A}$ & $\mathrm{D}$ & 383 & 83 & 5,508 & 56 & $\mathbf{6 , 0 3 0}$ \\
& & $\mathrm{N}$ & 602 & 456 & 3,674 & 115 & $\mathbf{4 , 8 4 7}$ \\
\hline \multirow{2}{*}{$10 \mathrm{~m}$} & $\mathrm{~A}, \mathrm{C}$ & $\mathrm{D}$ & 0 & 380 & 421 & 15 & $\mathbf{8 1 6}$ \\
& & $\mathrm{N}$ & 37 & 265 & 74 & 74 & $\mathbf{4 5 0}$ \\
\hline \multirow{2}{*}{$15 \mathrm{~m}$} & $\mathrm{~B}, \mathrm{C}$ & $\mathrm{D}$ & 0 & 82 & 1,938 & 0 & $\mathbf{2 , 0 2 0}$ \\
& & $\mathrm{N}$ & 0 & 0 & 1,970 & 1 & $\mathbf{1 , 9 7 1}$ \\
\hline \multirow{2}{*}{$20 \mathrm{~m}$} & $\mathrm{~B}$ & $\mathrm{D}$ & 0 & 0 & 0 & 0 & $\mathbf{0}$ \\
& & $\mathrm{N}$ & 0 & 12 & 93 & 0 & $\mathbf{1 0 5}$ \\
\hline \multirow{2}{*}{$25 \mathrm{~m}$} & $\mathrm{~B}, \mathrm{C}$ & $\mathrm{D}$ & 0 & 23 & 61 & 0 & $\mathbf{8 4}$ \\
& & $\mathrm{N}$ & 0 & 9 & 11 & 0 & $\mathbf{2 0}$ \\
\hline Total & - & D & $\mathbf{1 , 3 3 1}$ & $\mathbf{1 , 5 8 5}$ & $\mathbf{1 2 , 8 6 1}$ & $\mathbf{7 6}$ & $\mathbf{1 5 , 8 5 3}$ \\
& & N & $\mathbf{1 , 7 1 1}$ & $\mathbf{9 7 7}$ & $\mathbf{1 0 , 1 3 2}$ & $\mathbf{2 0 5}$ & $\mathbf{1 3 , 0 2 5}$ \\
\hline
\end{tabular}

*significant at $<0,05$.

Overall, in spite of the higher catch rate during the day (15,853 shrimp), there was a significant difference from the night samples $(13,025)\left(\mathrm{X}^{2} \mathrm{p}=3.48 \mathrm{E}-62\right)$. The number of individuals increased at night in spring (205 ind. at night and 76 ind. in daytime $-\mathrm{X}^{2}: \mathrm{p}=1.40$ E-14) and in summer (1,711 ind. at night and 1,331 ind. in daytime $\left.-\mathrm{X}^{2}, \mathrm{p}=5.58 \mathrm{E}-12\right)$. In the other seasons, the contrary was observed: in autumn, 977 shrimps were collected at night, and 1,585 during the day $\left(\mathrm{X}^{2}, \mathrm{p}=\right.$
3.07 E-33); and in winter, 10,132 shrimps were caught at night, and 12,861 in daytime $\left(\mathrm{X}^{2}, \mathrm{p}=2.04 \mathrm{E}-72\right)$ (Fig. 2).

The number of individuals differed significantly on most transects $\left(X^{2}(1-m) p=7.22 \mathrm{E}-30 ;(5-\mathrm{m}) \mathrm{p}=8.02\right.$ $\mathrm{E}-30$; (10-m) $\mathrm{p}=8.11 \mathrm{E}-25$; (20-m) $\mathrm{p}=1.22 \mathrm{E}-24$; $(25-\mathrm{m}) \mathrm{p}=3.48 \mathrm{E}-10)$. On nearly all the transects, the abundance was greater during the day. However, this occurred only at the locations with muddier sediments 


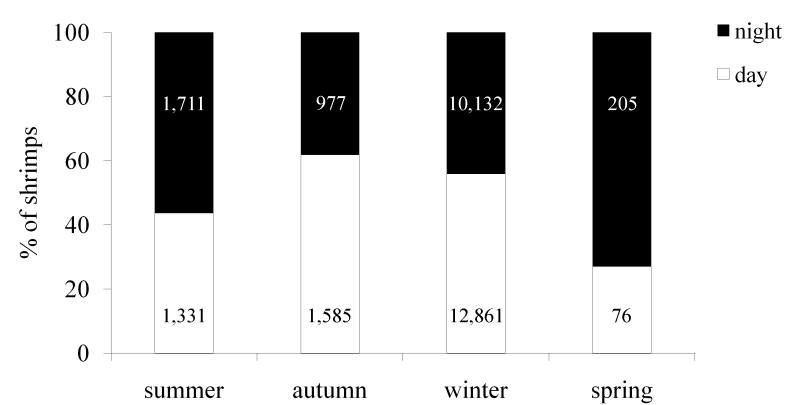

Fig. 2 - Percent variations of individuals of Xiphopenaeus kroyeri collected in the day and night periods, by season (summer, autumn, winter and spring). Numbers of individuals are inside of the bars.

(phi >4). In contrast, at the 20-m depth, shrimps were caught only at night. At this point, the values of (phi) decreased to close to 3 , that is, very fine sand predominated (Fig. 3). The same pattern was observed for juveniles, although the catches at the $10\left(\mathrm{X}^{2}, \mathrm{p}=0.001\right), 15\left(\mathrm{X}^{2}\right.$, $\mathrm{p}=0.02)$ and $20-\mathrm{m}\left(\mathrm{X}^{2}, \mathrm{p}=0.07 \mathrm{E}-10\right)$ depths differed significantly (Fig. 4).

The overall mean size (CL) of individuals was $14.43 \mathrm{~mm}$ in day samples and $14.82 \mathrm{~mm}$ in night samples, which is a significant difference (Student's $t$-test, df $=2429, \mathrm{t}=2.27, \mathrm{p}=0.02)$. The largest individuals, including all those with a carapace length above $28 \mathrm{~mm}$, were caught at night (Fig. 5).

Comparing the seasons of the year, the mean size of the individuals was larger in night samples, but a statistical difference was apparent only in autumn (Student's $t$-test, $\mathrm{df}=541, \mathrm{t}=2.08, \mathrm{p}=0.03$ ) (Fig. 6). In terms of spatial relationships, except for the $15-\mathrm{m}$ depth, the mean carapace size of adults collected at night was larger than the carapace size found in the day samples. The largest individuals were collected at the deeper localities, 15 and $20 \mathrm{~m}$ (Fig. 7).

\section{DISCUSSION}

The catch rate of individuals of $X$. kroyeri was slightly higher in daytime. This result contrasts with the majority of studies on marine shrimps, mainly of the superfamily Penaeoidea (see, Fuss Jr and Ogren 1966, PérezFarfante 1971, Cobb et al. 1973, Bauer 1985, Scelzo 2003). In the same region of this study, Lopes et al. (unpublished data) found that for two species of pink shrimp, Farfantepenaeus brasiliensis and F. paulensis, larger numbers of them were caught at night.
Diurnal burying activity is common in the majority of penaeids (Bishop et al. 2008). The burrowing behavior of penaeids is a strategy for energy conservation, as well as a means of defense against potential predators (Kutty and Murugopoopathy 1968, Dall et al. 1990). Shrimps that bury themselves in the substrate during the day are protected against predators that feed in this period, and are less active than those that do not bury.

Penn (1984) developed three models for burying behavior, based on studies with penaeids caught in the Gulf of Mexico: Type 1 - Strongly nocturnal, but often inactive or buried at night, although always buried during the day. The species included here are generally fished for in sandy substrates with relatively clear water; Type 2 - Generally nocturnal and continually active at night, and buried during the day but with a tendency to emerge occasionally. These species differ from Type 1 in being generally associated with muddier substrates. Such areas generally have more turbid water; Type 3 Rarely bury themselves and almost continually active. These are almost exclusively found in areas of river discharge, which are characterized by high turbidity.

For Xiphopenaeus kroyeri, it is difficult to propose a single pattern in conformity with these three models. Our results showed that, the sediment type of the study area, the size of individuals also affected the catch pattern. At $20 \mathrm{~m}$ depth, the shrimps were only found at night, the individuals presented largest sizes, and the sediment was composed of sand and, consequently, at this depth, the shrimps would be considered of the Type 1 . In contrast, for the shallower depths, the Type 3 pattern could be proposed because there was no great numerical change in catch rate between day and night. Silt and clay predominated at those locations, suggesting that the water there may be more turbid. In this respect, both the juveniles and adults of $X$. kroyeri showed the same behavior.

Laboratory experiments with $X$. kroyeri corroborate our proposal, since the shrimps buried themselves during the day and emerged at night in sediments composed of fine and very fine sand. When the shrimps were placed on muddy substrates, they began to burrow, but stopped immediately when the water became turbid. They did not cover themselves completely with sediment, and remained with only their body inside the small 


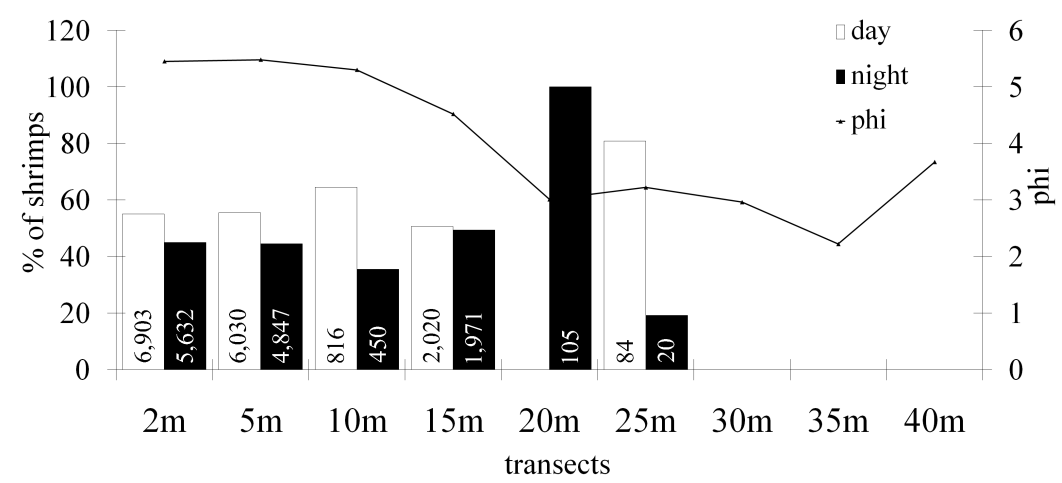

Fig. 3 - Values of phi and percent variations of individuals of Xiphopenaeus kroyeri collected in the day and night periods, by transect. Numbers of individuals are inside of the bars.

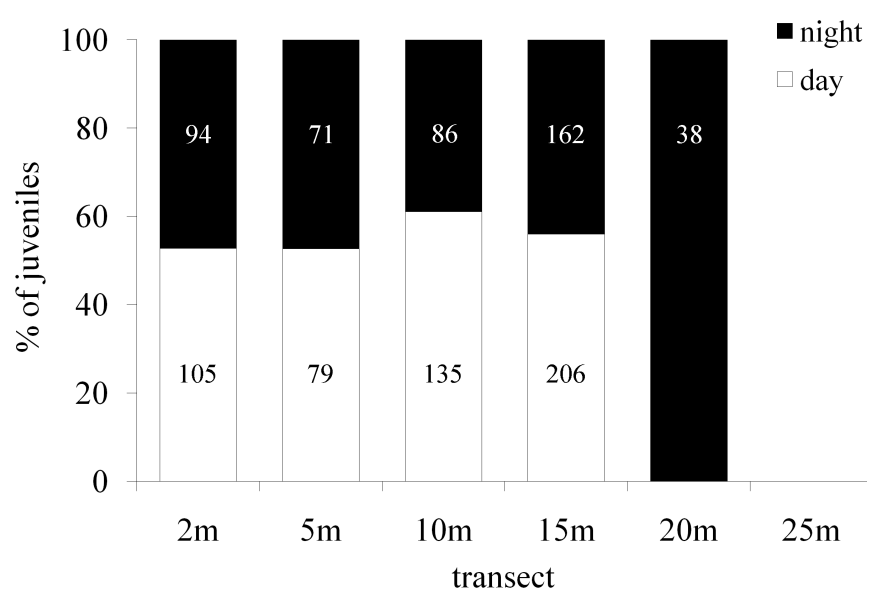

Fig. 4 - Percent variations of juveniles of Xiphopenaeus kroyeri collected in the day and night periods, by transect. Numbers of individuals are inside of the bars.

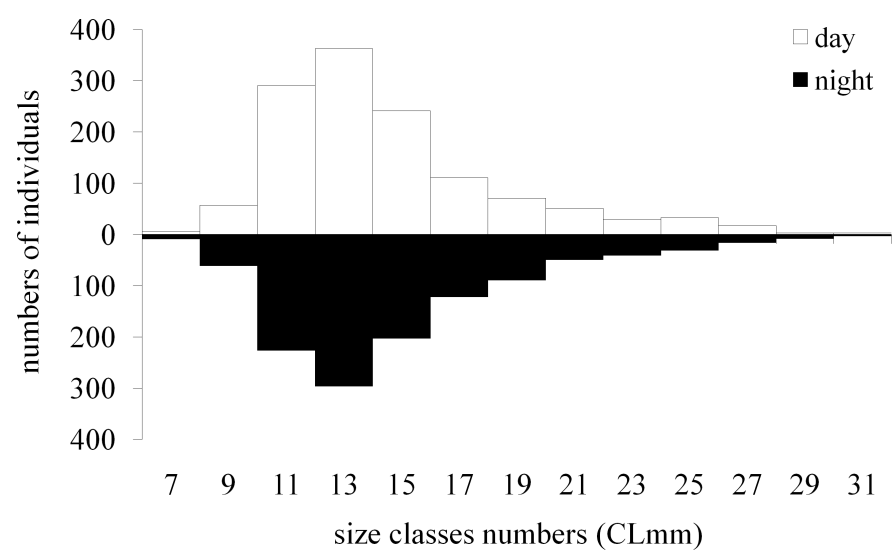

Fig. 5 - Numbers of individuals of Xiphopenaeus kroyeri by size class, according to carapace length (CL, mm), during the day and night. The range of each size class was $2 \mathrm{~mm}$; the value shown on the graph is the mean. 


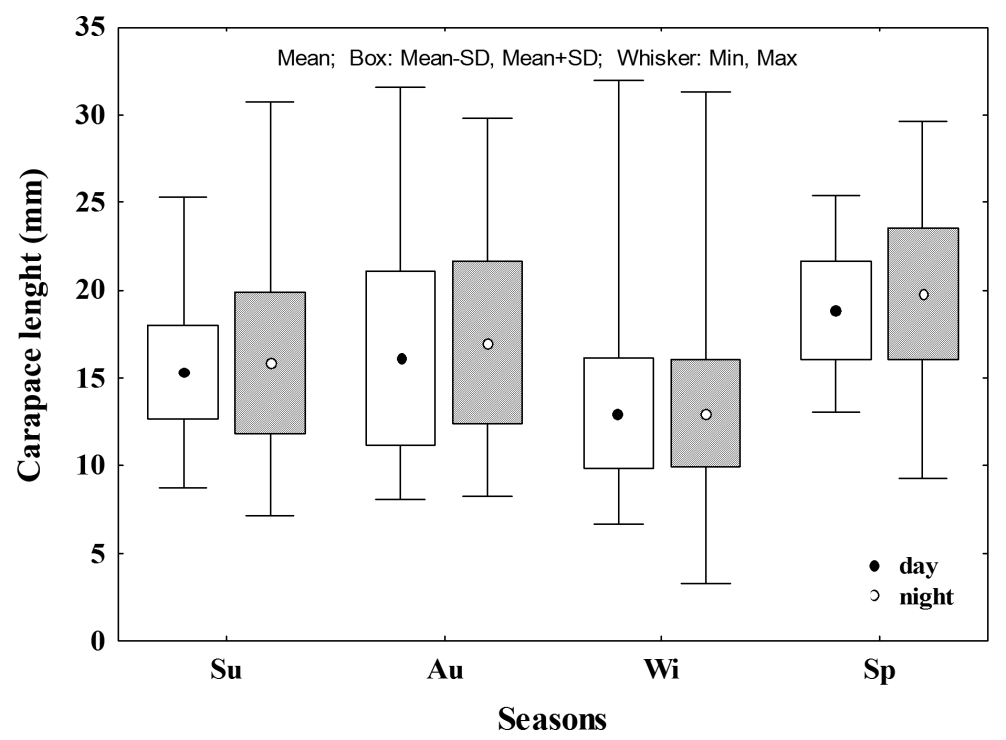

Fig. 6 - Means of sizes of individuals of Xiphopenaeus kroyeri (CL, $\mathrm{mm}$ ) in the day and night periods, by season. $\mathrm{Su}=$ summer, $\mathrm{Au}=$ autumn, $\mathrm{Wi}=$ winter and $\mathrm{Sp}=$ spring.

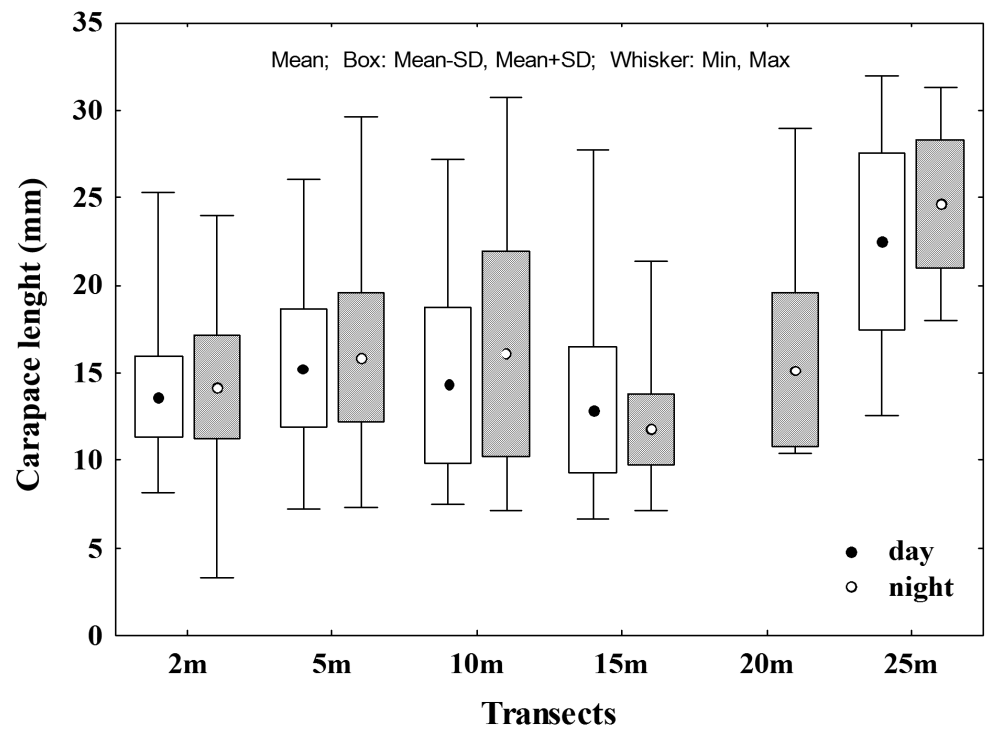

Fig. 7 - Means of size of individuals of Xiphopenaeus kroyeri (CL, mm) in the day and night periods, by transect. Asterisk indicates a significant difference (Student's $t$-test) between sampling periods.

hole that they had dug (F.A.M. Freire et al., unpublished data). According to Penn (1984), other penaeid species such as Penaeus indicus H. Milne Edwards, 1837, P. merguiensis De Maan, 1888, and P. setiferus (Linnaeus, 1767) do not burrow in very soft sediments because they are not capable of reversing the water flux that passes through their branchial chamber in order to avoid clogging (Penn 1984).

Seasonally, the wind action in the study region can also modify the pattern of capture of the individuals. 
The suspension of the substratum is caused many times because the wind action (Pedersen et al. 1995) and, consequently, increasing the turbidity of the water. In accordance with Castro-Filho et al. (1987), the strongest winds in the winter induces the penetration of Tropical Water straight to the direction to the coast, destroying the seasonal thermocline formed by the action of the South Atlantic Central Water and directing these masses to the continental slope. Although we did not analyze the wind action in the present study, this fact could have favored the increase of the water turbidity in the autumn and winter months and, consequently, allowing the increase of the individuals captured during the day.

With respect to size, our results agree with the findings of Negreiros-Fransozo et al. (1999), who collected the largest individuals at dusk. According to Dall et al. (1990), juvenile penaeid shrimps do not show a strong response of burying behavior in relation to light as the adults do, which are more caught during the night. In part, this hypothesis can be supported here, in that the smaller individuals of $X$. kroyeri were caught in about the same numbers in both periods, and the larger individuals were collected more often during the night. However, the adults, even smaller-sized ones, when in shallower areas, showed the same behavior as the juveniles. Experimental studies involving these demographic classes in different types of sediment between the day and night periods might elucidate this question.

The abundance of juveniles and adults varies seasonally in the study region (Costa et al. 2007), mainly due to the changes of the monthly temperatures values. The present study corroborates the results above. Moreover, beyond autumn and winter present values of bottom temperatures higher than spring and summer ones (Costa et al. 2007), we also suggest that the highest number of individuals in this period could be the result of the offseason period (March to May) for all the shrimps. In this way, the unification of the closure period as presently proposed for the pink and seabob shrimps is supported by this study.

In general, we can conclude that, for X. kroyeri, the sediment type is the main factor that affects the catch rate during the day and night periods. Nevertheless, other studies involving the comparison of diel catch rates of this shrimp for different demographic classes (juveniles, adult males, and ripe and spent females) in relation to lunar phases and the tidal cycle may contribute to a greater understanding of its behavior.

\section{ACKNOWLEDGMENTS}

We are grateful to the "Fundação de Amparo à Pesquisa do Estado de São Paulo" (FAPESP) for providing financial support (\#94/4878-8, \#97/12108-6, \#97/121063 , \#97/12107/0, and \#04/07309-8). We are also thankful to the NEBECC co-workers for their help during field work and to Dr. Janet Reid for her great help with the English language. All experiments conducted in this study comply with current applicable state and federal laws.

\section{RESUMO}

O objetivo do presente estudo foi analisar a variação diuturna na abundância e no tamanho do camarão sete-barbas Xiphopenaeus kroyeri na região de Ubatuba/São Paulo, durante o ano 2000. Em cada estação do ano, as coletas foram realizadas no período diurno e noturno, em 9 transectos localizados nas profundidades de 2 a $40 \mathrm{~m}$. Um total de 28.878 camarões foi obtido e apesar da maior taxa de captura observada durante o dia (15.853 camarões), não houve diferença significativa em relação ao período noturno (13.025). Na maioria dos transectos houve também uma maior taxa de captura de camarões durante o dia, no entanto, verificou-se que em locais com sedimentos com predominância de areia fina e muito fina, houve uma captura no período noturno. Já em relação aos juvenis, a maioria dos indivíduos foi amostrada durante o dia. Em consideração ao tamanho (CC) médio, obteve-se o valor de 14,43 \pm $4,02 \mathrm{~mm}$ durante o dia e 14,82 $\pm 4,28 \mathrm{~mm}$ durante a noite, com significativa diferença (Student's $t$-test, $\mathrm{df}=2.429, \mathrm{t}=$ $2,27, \mathrm{p}=0,02)$. Verificou-se também que os maiores indivíduos foram capturados no período noturno. Um único modelo dos três propostos na literatura para as espécies de peneídeos quanto ao padrão de captura diuturna não pode ser aplicado ao $X$. kroyeri. Nossos resultados evidenciaram que tipo de sedimento não somente influenciou na taxa de captura entre os períodos analisados como determinou os modelos em que esta pode ser incluída.

Palavras-chave: abundância, distribuição, Penaeidae, Xiphopenaeus kroyeri. 


\section{REFERENCES}

BAUER RT. 1985. Penaeoid shrimp fauna from tropical seagrass meadows: Species composition, diurnal, and seasonal variation in abundance. Proc Biol Soc Wash 98: 177-190.

BAUER RT AND LIN J. 1994. Temporal patterns of reproduction and recruitment in populations of the penaeid shrimps Trachypenaeus similis (Smith) and T. constrictus (Stimpson) (Crustacea: Decapoda) from the north-central gulf of Mexico. J Exp Mar Biol Ecol 182: 205-222.

Bertini G, Fransozo A And Costa RC. 2001. Ecological distribution of three species of Persephona (Brachyura: Leucosiidae) in the Ubatuba region, São Paulo, Brazil. Nauplius 9: 31-42.

Bishop JM, Ye Y, Alsaffar AH, Al-Foudari HM AND AL-JAZZAF S. 2008. Diurnal and nocturnal catchability of Kuwait's commercial shrimps. Fish Res 94: 58-72.

Castilho AL, Pie Mr, Fransozo A, Pinheiro AP AND CostA RC. 2008. The relationship between environmental variation and species abundance in shrimp community (Crustacea: Decapoda: Penaeoidea) in south-eastern Brazil. J Mar Biol Assoc UK 88: 119-123.

Castro RH, Costa RC, Fransozo A and ManteLATTO FLM. 2005. Population structure of the seabob shrimp Xiphopenaeus kroyeri (Heller, 1862) (Crustacea: Penaeoidea) in the littoral of São Paulo, Brazil. Sci Mar 69(4): 105-112.

Castro-Filho BM, Miranda LB And Myao SY. 1987. Condições hidrográficas na plataforma continental ao largo de Ubatuba: variações sazonais e em média escala. Boletim do Instituto Oceanográfico 35(2): 135-151.

CoBb SP, Futch CR AND CAMP DK. 1973. The rock shrimp, Sicyonia brevirostris Stimpson, 1871 (Decapoda, Penaeidae). Mem Hourglass Cruises 3: 1-38.

Costa RC And Fransozo A. 2004. Reproductive biology of the shrimp Rimapenaeus constrictus (Decapoda: Penaeidae) in the region of Brazil. J Crust Biol 24: 274 281.

Costa RC, Fransozo A, Freire FAM and CAstilho AL. 2007. Abundance and ecological distribution of the "sete-barbas" shrimp Xiphopenaeus kroyeri (Heller, 1862) (Decapoda: Penaeoidea) in three bays of the Ubatuba region, south-eastern Brazil. GulfCaribbean Res 19: 33-41.

Dall W, Hill BJ, Rothilsberg PC and Staples DJ. 1990. The biology of the Penaeidae. Advances in Marine Biology. Blaxter JHS ANd Southward AJ (Eds), San Diego, Academic Press, p. 1-489.
D'InCAO F, VALENTINI H AND RodRigues LF. 2002. Avaliação da pesca de camarões nas regiões Sudeste e Sul do Brasil. Atlântica 24(2): 103-116.

Fransozo A, Costa RC, Pinheiro maA, Santos S AND Mantelatto FLM. 2000. Juvenile recruitment of the seabob Xiphopenaeus kroyeri (Heller, 1862) (Decapoda, Penaeidea) in the Fortaleza Bay, Ubatuba, SP, Brazil. Nauplius 8(2): 179-184.

Fransozo A, Costa RC, Mantelatto FLM, Pinheiro MAA AND SAntos S. 2002. Composition and abundance shrimp species (Penaeidea and Caridea) in Fortaleza bay, Ubatuba, São Paulo, Brasil. In: Moddern Approaches Study 14 Crustacea, BRIONES E AND ALVAREZ F (Eds), Kluwer Academic Publishers, p. 117-123.

FUSS JR CM AND OGREN LH. 1966. Factors affecting activity and burrowing habits of the pink shrimp, Penaeus duorarun Burkenroad. Biol Bull 130: 170-191.

Gusmão J, LAzoski C, Monteiro FA And SolÉ-CAVA AM. 2006. Cryptic species and population structuring of the Atlantic and Pacific seabob shrimp species, Xiphopenaeus kroyeri and Xiphopenaeus riveti. Mar Biol 149: 491-502.

Kutty MN AND Murugopoopathy G. 1968. Diurnal activity on the prawn Penaeus semisulcatus De Haan. J Mar Biol Assoc India 10: 95-98.

LAPRise R AND Blader SJM. 1992. Predation by Moses perch, Lutjanus russelli, and blue-spotted trevally, Caranx bucculentus, on juvenile brown tiger prawn, Penaeus esculentus: effects of habitat structure and time of day. J Fish Biol 40: 627-635.

Mantelatto FLM And Fransozo A. 1999. Reproductive biology and moulting cycle of the crab Callinectes ornatus (Decapoda: Portunidae) from the Ubatuba region, São Paulo, Brazil. Crustaceana 72: 63-76.

MAntelatto FLM AND Fransozo A. 2000. Brachyuran community in Ubatuba Bay, Northern Coast of São Paulo State, Brazil. J Shellfish Res 19(2): 701-709.

Minello TJ, Zimmerman RJ and Martinez EX. 1987. Fish predation on juvenile brown shrimp, Penaeus aztecus Ives: Effects of turbidity and substratum on predation rates. Fish Bull 85: 59-70.

Moctezuma MA And Blake BF. 1981. Burrowing activity in Penaeus vannamei Boone from the CaimaneroHuizache Lagoon system on the Pacific Coast of Mexico. Bull Mar Sci 31(2): 312-317.

NAKAgaki JM and Negreiros-Fransozo ML. 1998. Population biology of Xyphopenaeus kroyeri (Heller, 
1862) (Decapoda: Penaeidae) from Ubatuba Bay, São Paulo, Brazil. J Shellfish Res 17(4): 931-935.

Negreiros-Fransozo ML, REIGAdA ALD AND NAKAGAKI JM. 1999. Diel variations in decapod catch rate and size of captured individuals in a subtropical area of Brazil. In: SCHRAM FR (Org), The Biodiversity Crisis and Crustacea, $1^{\text {st }}$ ed., Leiden, Brill 2: 643-656.

PAIVA MP. 1997. Recursos pesqueiros estuarinos marinhos do Brasil. Edições UFC, Fortaleza, 278 p.

Pedersen OB, Christiansen C and Laursen MB. 1995. Wind induced long term increase and short term flutuations of shallow waters suspend mater and nutrient concentrations, Ringkobing Fjord, Denmark. International J Mar Biol 41: 273-287.

PENN JW. 1984. The behavior and catchability of some commercially exploited penaeids and their relationship to stock and recruitment. In: Penaeid Shrimps - The Biology and Management, Gulland JA AND RPTHSCHIID BJ (Eds), Fishing News Books Limited, Farnham, p. 173-186.
PÉREZ-FARfante I. 1971. Range extension of shrimp Penaeus (Melicertus) brasiliensis Latreille, 1817 (Decapoda, Penaeidae). Bull Mar Sci 21(3): 745-746.

Pérez-Farfante I And Kensley B. 1997. Penaeoid and Segestoid shrimps and Pawns of the World. Keys and diagnosese for the families and genera. Éditions du Muséum national d'histoire naturalle. Paris, $233 \mathrm{p}$.

SCELzo MA. 2003. Day and night abundance and density of juveniles pink shrimps Farfantepenaeus notialis (PérezFarfante) and Farfantepenaeus brasiliensis (Latreille) in La Restinga lagoon, Margarita Island, Venezuela (Decapoda, Penaeidae). Nauplius 1: 1-13.

SogARD SM AND ABLE KM. 1994. Diel variantion in immigration of fishes and decapod crustaceans to artificial seagrass habitat. Estuaries 17(3): 622-630.

ZAR JH. 1999. Biostatistical analysis. Prentice Hall, New Jersey, p. 1-663. 